\title{
Policy Analysis on ICT in Education: A Case of Public High Schools in New Juaben Municipal of Ghana
}

\author{
Annor Prince* $^{*}$ Osman Issah Fuseini Clement Nana Kofi Appiah \\ School of Public Affairs and Administration, University of Electronic Science and Technology of China, \\ P.R. China Address: No.2006,Xiyuan Ave.West Hi-Tech.Zone,P.R.China \\ Post Code: 611731
}

\begin{abstract}
ICT has brought some degree of changes in every bit of our daily life from education, health, sports etc. Educators and governments have also devoted huge resources to the provision of technology in the learning environment. Despite the increase in ICT tools in Ghanaian Senior High schools, most of the schools seem to be teaching ICT literacy instead of complete integration of the ICT tools in the curriculum to enhance the teaching and learning process. This study assessed whether ICT policy has accomplished its aim, thus enhancing the teaching and learning process in all the five schools in the New Juaben District of the Eastern Region. A purposive sampling method was used in the selection of the participants. The selected participants consist of administrators and teachers which was taken from all the five senior high schools for the interview. The main findings of the study were that most of the teachers lack training and knowledge about computers and have no previous experience in the use of computers. Also, inadequate ICT infrastructure in the schools was the other major factors inhibiting the integration of ICT into the learning and teaching process. Furthermore, it was found that there were schools which after receiving technical equipment failed to use equipment properly due to negligence and irresponsibility. Moreover, the study revealed that lack of training and technical knowledge made it difficult for teachers to make use of the given equipment. Finally, it was revealed through the study that majority of the participants considered the use of the ICTs as the preferred of the younger generation and that ICT should be taught as a subject on its own and not integrated into all the other subjects.It is recommended that ICT infrastructures should be provided to the Senior High Schools for effective teaching and learning process since it is the basic stage of equipping the youth with the necessary skills and knowledge for national development. Teachers should be given the necessary training in ICT usage so that they become familiar with the modern pedagogy of imparting knowledge and skills, and possibly become part of the curriculum structure for their professional training. Governments ought to move forward the training of principals, teachers and computer staff on the utilize of computers and other ICT tools through seminars, workshops and in-service training.
\end{abstract}

Keywords: ICT in Education, Policy Implementation, High School, New Juaben.

DOI: $10.7176 /$ PPAR/9-7-05

Publication date:July $31^{\text {st }} 2019$

\subsection{INTRODUCTION}

The change in the speed of technology is now so fast that schools cannot afford to be left out: new technology that improves the learning experience for students, by teaching them ways to access information for themselves must be embraced by schools. (Watson, 2001). The focus of academics needs to be geared further towards 'learning how to learn', complemented by the encouragement of lasting learning and adaptability, since today's tools used will rapidly be superseded with the advancement in technology (Jordan \& Follman, 1983). The students must be educated by schools on how to use today's technology tools to promote their individual learning skills and gain the discipline of a long-life agenda for the lengthier term. As determined by the International Labour Organization (Rubery, 2003), it will be a prerequisite that everybody at the most minimum achieves basic education and fundamental work skills and train in lifelong learning, the essential requirements for education and training as a new shape to the global economy emerges. Information and Communication Technologies (ICTs) are primarily the technological tools most often considered for enabling educational reforms these include digital television, radio, computers and the internet, network hardware and software (Tinio 2003). It has been shown that when ICT is used appropriately it increases educational quality by providing the opportunity for tutors to make lessons more engaging, motivating and thereby an active process connecting lessons to real life (Tinio, 2002). However, it is important for educationalists to effectively utilize the benefits that ICT offers to more broadly enrich the experiences of learners because simply access to technology in the school does not automatically improve learning or, in itself, promote good practice: (Noor-Ul-Amin, 2013). Teachers need to look at the design of their curriculum, their use of appropriate pedagogy, once ICT facilities are available in the classroom. This comes down to the readiness of institutions and teachers to adjust and upgrade their skills and competencies for them to be able to make use these new and powerful tools at their most effective to develop their students' abilities. 
In the educational environment, today's teachers and students have an opportunity to use various types of resource offered by information technology. The internet, for example, students can extensively use it to obtain necessary and pertinent information from original sources such as government offices, universities and companies, as the web is deemed to be like a worldwide library (Paris, 2002) [7].

In the UK much investment has been done in information and communication technology (ICT) for it to be used in schools by pupils and teachers. The one computer for every three pupils' ratio which is highest in the European Union, is a result of very significant investment in ICT since 1997 by UK Government, totaling some $£ 5$ billion (Isaacs 2011). Furthermore, for more than two decades now, educational technologies have now been in use in the UK. However, despite making substantial investments in ICT, there is remarkably little data or analysis about the use of computers in schools and other ICT equipment. However, the involvement of Information Communication Technology (ICTs) in African countries and Ghanaian schools are generally on the increase and intensely growing (Tella \& Adeyinka, 2007). While there is in-depth information about the use of ICT in high schools that are found developed nations, Ghana lacks those abilities and do not have much data and information on the use of ICT by instructors in most of our Ghanaian schools. Also, between rural and urban schools, there is a suspicion that with the utilization of ICTs, there is a wide gap. (Aduwa-Ogiegbaen \& Iyamu, 2005). Ghana's government has laid emphasis that ICT plays a bigger role in contribution of the country's economic development. The country's medium-term advancement arranges stated in the Ghana Poverty Reduction Technique Paper (GPRS I\&II) and the Education Strategic Plan 2003-2015 all propose the use of ICT as a medium of reaching out to the poor in Ghana (Government of Ghana,2003). In 2004, Ghana's ICT for Quickened Development (ICT4AD) policy was passed into law by parliament and is currently at different stages of execution. Ministry of Education out of this arrangement delivered an ICT in education system archive to integrate ICTs in schools. It is worth taking note that the ICT in instruction arrangement for Ghana had a long development period. An endeavor at policy advancement for the segment originates before the national ICT approach.

In Ghana's context, a rapid transformation has been observed in the role of the teacher in recent years. There are many new changes and challenges that teachers face and are required to adapt to. Included in this are more contemporary and westernized approach from schools; new teaching methods and learning, growth in student numbers, and (most importantly) an explosion in the development of teaching with ICT. All of this means teachers must update their knowledge and skills for the development of the educational process in the classroom. With the approach of modern reasoning towards ICT and its role in education, a wide body of research has created investigating the role and impact of ICT in developing an interactive educational environment. A significant number of researchers have provided evidence of the significant contribution that ICT makes to improving teaching methods and positively impacting the student (Kennewell and Beauchamp, 2007). Though, many of these research work has been limited to investigating the effect of ICT on learners, there is substantially less research work which focuses on the ICT's role in creating and promoting a more interactive educational environment, as part of teaching and learning. ICT's presence in the interactive educational atmosphere can help to progress thinking skills and make classrooms an environment for educational growth. ICT also helps students to create modern thinking abilities which may transfer to diverse situations which may require analysis and comprehension abilities, and consequently critical skill development (Al Hudhaifi and Al Dughaim, 2005). Integrating ICT into High school education is faced with various challenges on a face-value raging from ICT infrastructural development in high schools, teaching and learning materials used in classrooms, poor teaching skills, implementation of ICT policies and many more which needs to be verified empirically through research. It is in this regard that this study sought to determine the: role ICT plays in high school education in Ghana; challenges schools face in the ICT integration process; challenges administrators face in the implementation of ICT in government high schools in Ghana; and effect ICT has on education in government high schools in Ghana.

\subsection{Research Framework}

This section of study depicts the researcher trying to identify potential causes that delimit ICT implementation (Information Communication Technology) in education and this is assessed from socio-economic, Physiological and political perspective. If these matters are identified, the existing policy will be very easy to be implemented. Therefore, the outcome of analyzing the existing policy, evaluating the efficacy and effectiveness of these responses to the policies, and recommending policy in the context of political, socio-economic, Physiological view of using ICT will result in public wellbeing since almost all manual methods of doing things are being replaced by the use of computer. 
Figure 1. Conceptual framework

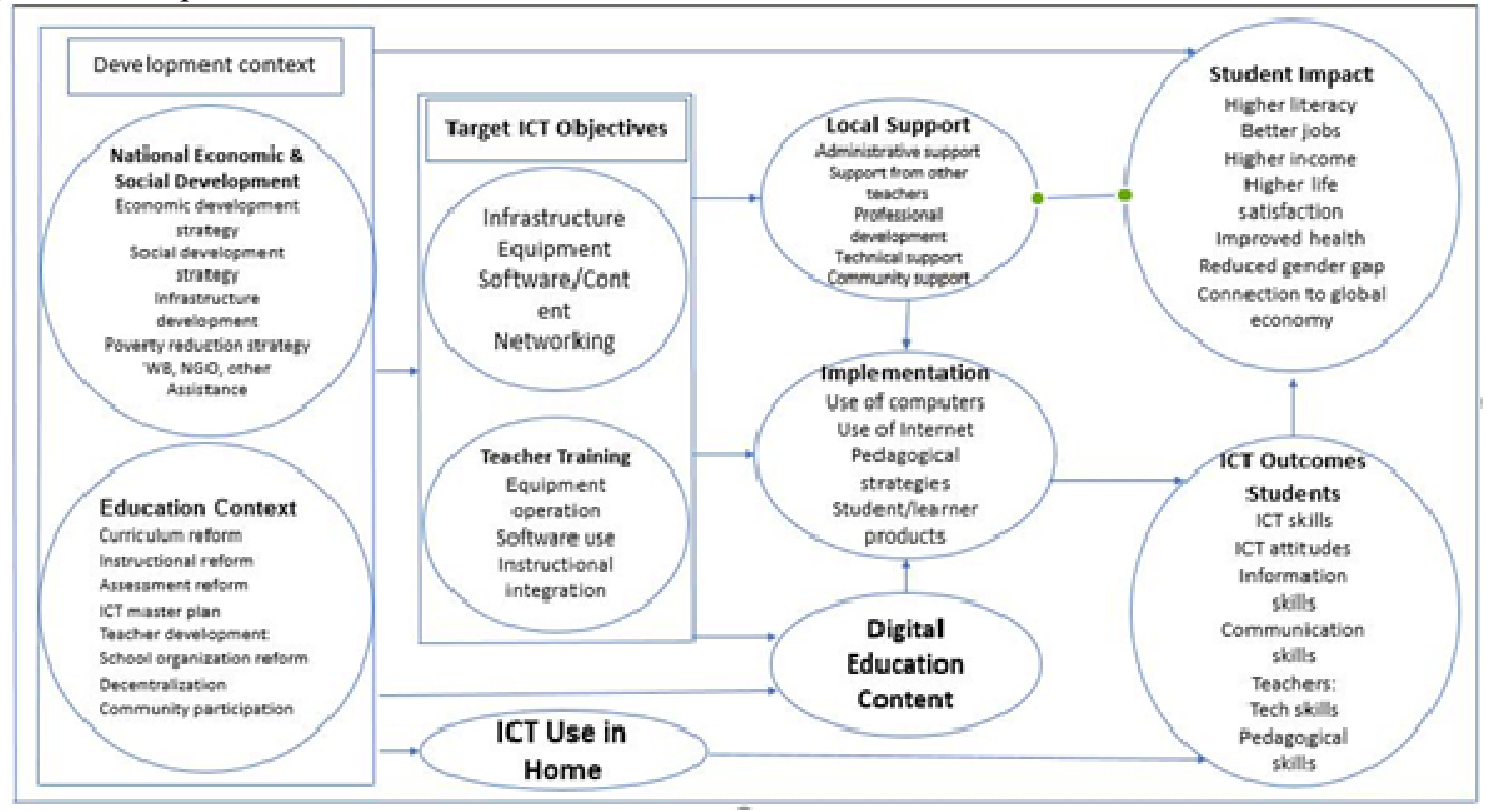

\subsection{LITERATURE REVIEW}

The study presented on the core concepts; theories; policy reviews on ICT in education in both Ghana and abroad.

\subsection{Policy}

The CDC definition of "Policy" is "a law, control, method, regulatory activity, motivation or intended practice of governments and other institutions." (CDC, 2011). Policies generally work at the systems level and can impact complex frameworks in ways that can improve the wellbeing and security of a population. A policy approach can be a cost-effective way to make positive changes in the wellbeing of huge portions of the population. There are a few sorts of policy, each of which can operate at distinctive levels (national, state, local, or organizational) (CDC, 2011). An example of government policymaking is undoubtedly where the government seeks to set out its approach to a particular society in an area in a White Paper or similar document. This might cover, for example, the policies of government pertaining to the macro or micro-economy, the health service or crime. Essentially, these policy statements seek to set out the government's whole analysis of a specific issue or set of issues; and to present its philosophy in relation to those issues. Policies appear in five broad interrelated categories. Each part may have an impact on the other category as indicated diagrammatically bellow.

Figure 2. Five Categories of Policy

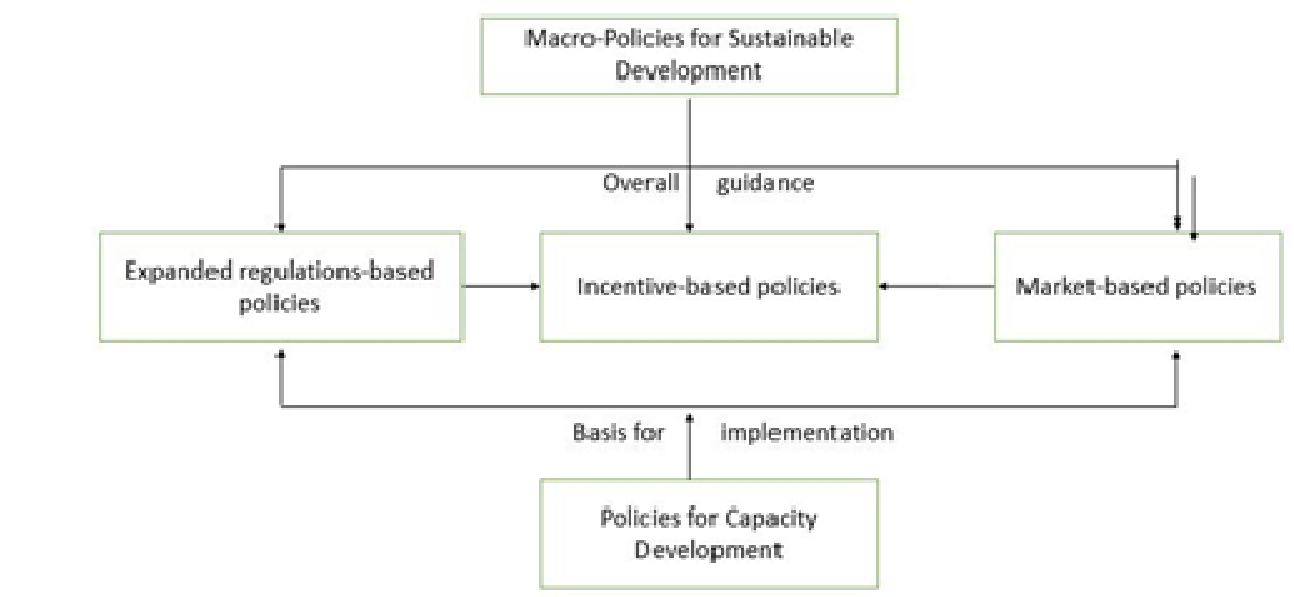




\subsection{ICT}

ICT Stands for "Information and Communication Technologies." It alludes to technologies that provide access to information via broadcast communications. It is comparative to Information Technology (IT) but focuses basically on communication innovations. This includes the Web, cell phones, wireless systems, and other mediums of communication. For the purposes of this study, ICTs is defined as an "innovative instruments of diverse set as well as resources used in communicating, and to make, disseminate, store, and oversee information" (Blurton, 2002). In recent time much interest has been in how computers and the Web can best be tackled to move forward the productivity and at all levels adequacy of education and in both formal and nonformal settings.

\subsection{Secondary Education}

Secondary Education. There are two phases of secondary education on the International Standard Classification. Level 2 or lower secondary school (less common junior secondary instruction) is noted to be the second and last stage of basic education and level 3 (upper) secondary education is the phase that comes before tertiary education. The supply of basic education is the aim of each nation, but the frameworks and terminology remain special to them. Secondary education regularly was undertaken after six years of primary education and is taken after by higher education, professional education or work (ISCED 1997). Like essential education, secondary education is obligatory in most nations, at least until the age of 16. Typically, children commence the lower secondary stage around the age of 11 . Obligatory education sometimes amplifies to 19 years of age. Education continues to be seen as an essential human right for a child since 1989.In article 28 of the Convention on the Rights of the Child states that: education at the primary level ought to be obligatory and free while distinctive forms of education at the secondary level, including common and vocational education be obtainable and reachable to every single child. The terminology has shown difficult, and there wasn't any general explanation before ISCED separated the period that comes between the primary level of education and university into junior secondary education and (upper) secondary education. During the classical and medieval times education at the secondary was given by the church for the children of nobility and to boys planning for priesthood and university as well. As exchange required navigational and logical skills the church reluctantly extended the curriculum and broadened the admissions. According to Comenius and John Locke, education transitioned from being redundancy of Latin text to encourage the buildup of information in the child, and with the Reconstruction the state wrestled the control of learning from the church (Crenshaw, 2013). Only a few had accesses to education. In 1868, a secondary level of schooling was composed to fulfill the needs of distinctive social classes with the group in the working classes getting 4 years, 5 years for the merchant class and the elite getting 7 years. As it were, it then ended up accepted that young ladies could also be sent to school. The rights to education at the secondary level were codified after 1945, and countries are still putting in much work to accomplish the objective of obligatory and free secondary education for all youths beneath 19 .

\subsection{Theory of Diffusion of Innovations}

According to Rogers (2010), diffusion investigates centers on the conditions, which increase or diminish the probability that individuals of a given culture will embrace an unused thought, item, or practice. According to Rogers people's demeanor toward a modern technology is an important component in its diffusion. The terms innovation and technology interchangeably were employed interchangeably by Roger (Rogers, 1995, p.12), the diffusion of innovation system appears particularly suited for the study of the diffusion of ICT. Roger's Innovation Choice Prepare theory states that innovation diffusion is a handle that happens over time through five stages: knowledge, influence, choice, execution and confirmation. Accordingly, the innovation-decision process can be defined as the process through which an individual or other decision-making unit passes from initial knowledge of innovation, attitude creation toward the innovation, to accepting or rejecting a choice, the execution of the innovative ideas, and to the validation of this decision. (Rogers, 1995),

Due to the uniqueness of computers and their related innovations, studies concerning innovation diffusion in education have regularly centered on the initial three stages of the development choice process. To an incredible degree, the status of computers in education is still unstable. In cases introduced of technology into the educational system has been in recent times, as is the case of most developing countries, the focus of study has mainly been on the initial two stages, which includes, on knowledge of an innovation and attitudes towards it. 
Figure 3. Diffusion of Innovation Diagram

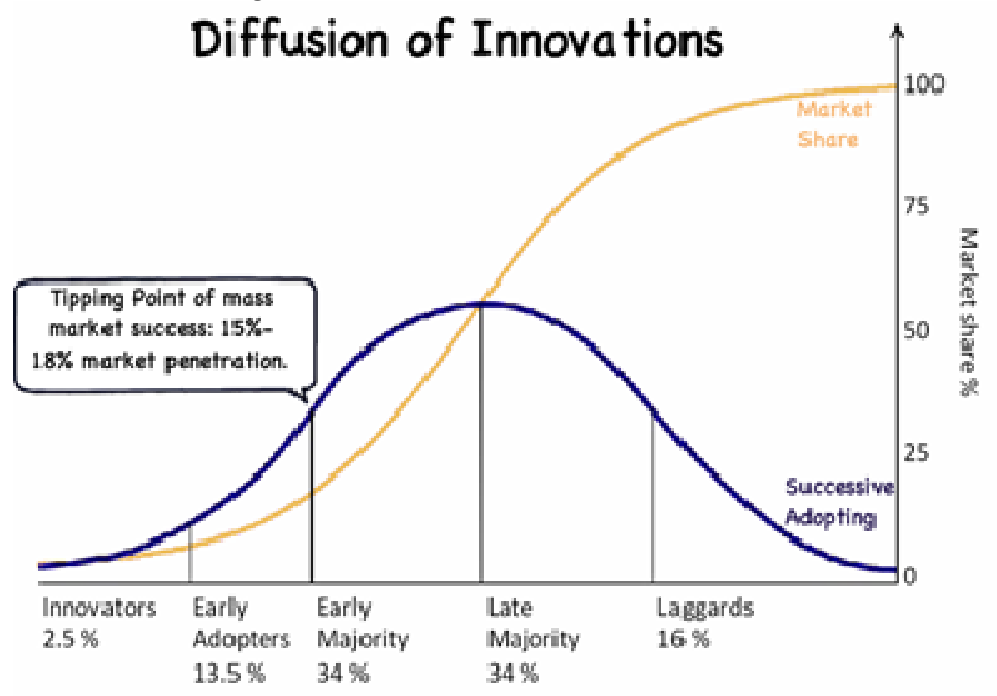

Innovations - is the act of bringing up an idea or something new or practice supposed by individuals as something new. Communication Channel - is the communication medium that takes information from one individual to another. Innovations spread faster through the various channels of communication such channels include word of mouth, SMS, any sort of literary form etc. Time - It refers to the period it takes to be familiar with innovations in a particular society. For ideas to get root in a community it takes time. let's consider computers, it took a while before was able to spread among its current users.

Social System - It refers to an interrelated organized group joined together to unravel the issues for a common goal. Social system alludes to all sorts of components which build the society like religion, educate, groups of individuals etc.

\subsection{Theory of Constructivism}

Constructivism is a philosophical theory that tries to appreciate how humans build an understanding of the world they live in. Crotty (2003) defined the epistemology as 'meanings are built by human beings as they contribute with the world they are interpreting' (p.4). Therefore, constructivism is deemed an appropriate perspective for this study, as teachers not only have the option of whether to integrate or reject different pedagogical practices and utilization of technology in their teaching, but the effect upon them by people who are influential regarding integration or rejection of that pedagogical practices and that technology inclusive (Venkatesh et al., 2003). ICT integration into educational practice may be perceived as a social phenomenon, with the benefits that derive from its integration or level of use being comprehended differently by promoters of technology (government and school leaders) and by participants (teachers) (Rogers, 1995). This is relevant within the constructivist perspective, as Marriam (1998) states that 'reality is created by individuals interacting with their social worlds' (p.6). Likewise, Ackerman (2001) also expressed this point, claiming that 'knowledge and the world are both constructed and constantly reconstructed through personal experiences' (p.7). As both individual teachers and ICT coordinators live and work together in wide ranges of social environments, 'multiple realities', as termed by Merriam (1998, p.4), may emerge because every teacher and ICT coordinator will have a different opinion of a particular instance. Examination of issues within such context leads to the adoption of an interpretive approach.

\subsection{Policy Reviews on ICT in Education in Ghana}

A review indicates that appropriate policy frameworks must control ICT initiatives to encourage excellent education (Toure, 2008; Gillard, Bailey \& Nolan, 2008; Takyi 2012; Oliver, 2002). Teacher training and new skills in partnership management are essential. In Africa, we require local, national and territorial endeavors that encourage development by teachers of fitting computerized resources made by and for Africans and others, otherwise we may value ourselves as unimportant consumers for the case of Microsoft encyclopedia Encarta Africana and Wikipedia. Therese Mungah Shalo Tchombe in her paper made reviews of gender differentials in the usage of ICT at school and deliver us with an intellectual framework for focusing on the use of technology in education, a system in which learning is considered useful rather than a receptive process and knowledge is made rather than exchanged or obtained. She contends that ICT in education, particularly in African settings, can move forward the value of instruction by supporting unused educational approaches where an instructor is more of a "guide on the side" than a "sage on the stage." As she puts it elsewhere, the study demonstrates "a few moves from textbook-based tutoring to the web-supported community of request (Toure, 2008). knowledge 
assets accessible in content-thin textbooks and constrained libraries could not maintain inquiry-oriented instructional method" (Tchombe, 2006) Prerequisites for utilizing ICT in transformative ways in educational settings which incorporate teachers who are sure and competent enough to direct technology use and students with adequate information base and cognitive abilities. Instructor training and curriculum modifications are in this way important.

A gender looks at access and compelling usage of ICT appears that boys have been favored when it comes to accessing technology, in portion due to socially built gender connections and roles. Investigate outcomes appear that young ladies are more centered on the errand at hand when is in use in school while boys are more exploratory and drawn to recreations. Tchombe stresses that gender particular pointers on ICT ought to be created, mainstreamed and checked in all ICT activities. She also over and over implies the importance of ICT for the comprehensive education that comes to students with learning troubles and challenged with physical or mental development. What will it take for ICT to promote the quality of education in economical ways? The paper by Adjibodou Aristide et al. fights that as is the case for most educational development, vision and administration are required - at the national level and at the school level, with expanded independence at every level. We require to instruct not fair "tech." We require imagination, not just information. And we need plans to guarantee ICT resources are accessible to those in rural areas.

A few West and Central Africa schools started spearheading the introducing ICTs such as computers and web in the late 1990s, with the small government back when national approaches on ICT in the segments of education were nonexistent. ERNWACA1 researchers, in the organization with the Montreal University and with back from the Universal Development Research Middle (IDRC), have researched procedures surrounding the introduction and use of ICT in teaching and learning process and learned lessons from early adopters in 36 schools, schools which emerged to be called "pioneer schools." Though there are dangers, with respect to time administration, monetary cost, directional techniques, and student advantage (Gillard, Bailey \& Nolan, 2008), why are some schools and teachers in Africa joining ICT into educating and learning? The studies in this collection will start to reply that question. Most of the studies show discoveries from the ERNWACA transnational investigate project, conducted in Benin, Cameroon, Ghana, Mali, and Senegal spanning from 2003 to 2005. The study included 66000 students and 3000 instructors including school executives and other administrators, educational advisors, and guardians. A case study of qualitative approach, utilizing interviews, focus group discussions and perception, was combined with a quantitative approach, using surveys to accumulate information on the scope and nature of instructors and student utilize of ICT. ERNWACA analysts confront and developing region in education research and wrestle with how to outline the questions in ways significant for communities on the landmass and elsewhere. They replied questions around the congruity of the use of ICT in education in Africa and raised others.

\subsubsection{ICT in Education: Laws and Institutions}

Legislation related to ICT in instruction does not have a comprehensive and unified legitimate framework. Setting up an adaptable lawful framework to receive and utilize cloud services, the Internet of Things, expanded and virtual reality, manufactured insights, big data, etc. is fundamental. Additionally, autonomous legislations related to ICT in an educational setting must be set up for the supply valuable and noteworthy administrations to education users through the merging of education and IT technologies.

The basic legislation of education and research-informatization field is rooted in the Basic Act on Education, Scientific Research Promotion Act, Basic Act on National Informatization and the like while the detailed legislation incorporated with it is independently provided as required centered on the said three acts. Three Acts may represent the trend of the law and governance regarding education informatization as of 2013: The three articles can be described as follows: Special Act on ICT Promotion and Convergence Activation: The leading one laid down is the IT Special Act, with regard to communications and information, after the MSIP was launched. Two components of the Act are to be highlighted as highly relevant to education informatization. First, is the fact that it runs the Basic Plan along a three-year cycle establishing its working plans every year and institutes as the deliberative legislative body the Committee of National Informatization Strategy. Second, is the fact that it prescribes software education to nurture experts in the information and communications fields and fostering industrial manpower via credit-offering internship qualified in agreement with the Higher Education Act; Criteria on the Attendance and Grading of Online Learning: The current Elementary and Secondary Education Act Article 1 and Enforcement Proclaim of the Basic and Secondary Education Act, through the utilization information and communications media, but the direction has been loose through the alteration on October 30, 2013 of the Authorization Declare of the Basic and Secondary Education Act with respect to the course through the use of information and communications media by permitting the director of education to indicate, if vital, the details regarding the subject and operating methods of the class. 


\subsection{Policy Reviews on ICT in Education International Trend}

The potential for and the role of ICTs in the educational sector is not an issue isolated from educational change efforts, but rather inseparably entwined. ICTs are vital tools to meet Development Objectives of access to and quality enhancements of educational programming for all children for thousand years. The literature review revealed a restricted pool of evaluations utilizing quantitative and mixed-methods procedures to evaluate the effects and impact of ICT intercessions on students' educational results in developing nations. Assessments that examined the impacts of ICTs on teacher results were avoided (e.g. Burns, 2006a; Burns, 2006b), education information administration frameworks (which include communication between networks of schools) and policy-level surveys on the "state of ICT" within countries. The number of case studies or absolute qualitative assessments, accessible for the survey was indeed smaller, but included a field study of a radio program planned to increase get to essential instruction for children in Zambia in a short-term (Hollow, 2006); an assessment of promising models of ICT integration in inaccessible zones and rural areas of Mongolia (Strigel, Ariunaa \& Enkhjargal, 2007); a policy-level assessment of the conditions beneath which Open Educational Assets (OER), digitized materials advertised openly and transparently for teachers, students and self-learners to utilize and reuse for teaching, learning and investigate education, progress information spread in sub-Saharan African countries (Mulder, 2008); and a field study investigating the ICTs role in the lives of low-literate youth in Malawi and Ethiopia (Geldof, 2008), among others. In the full-length report, we examine and display three assessments of qualitative educational interventions executing ICTs; these thoughts were chosen since they represent a different set of approaches and methodological thoroughness within the qualitative field. At the beginning, we talk about a project evaluation that coordinates handheld technologies in the enhancement of science and mathematics courses in Thailand; moment, we talk about a special comparative assessment of computer-based education programs in Chile and Costa Rica; at last, we talk about a pilot evaluation execution of One Child per laptop initiative in Ethiopia. The outcomes of these qualitative studies are blended, indicating to both positive and negative effects on student results of learning, but without quantitative confirmation of these outcomes, it is troublesome to discover the importance of these discoveries. Case studies alone do not give a thorough sufficient base from which to draw policy-relevant or automatic conclusions. Studies using strategies of both quantitative and qualitative approach will likely offer the most comprehensive appraisal of impact given that researchers can utilize measurable methods to recognize particular components that improve or dilute an intervention's viability and also investigate, through interviews and observations, why and how these constituents work.

Literature from Australia (Newhouse, 2002) and Great Britain (Bramall S. 2002) gives to prove that ICT emphatically impacts on student accomplishment in core subjects, including proving that particularly relates visual expressions and use to improve learning forms and results. Findings show that both the learning atmosphere and educational modules pedagogy and content are key to the successful use of ICT. However, instructors are required to be certain in their subject knowledge and also in the fundamental ICT literacies for them to successfully coordinate ICT into teaching programs. A lot of studies have shown that students are frequently more locked in and persuaded to memorize when using significant ICT to support specific intentional learning. Unintentional learning can be considered from the UK and Australia regularly to conclude that instructors require arranging for the ICT integration into educating and learning programs satisfy individual students' needs and the choice of quality computerized material. To this conclusion, various research work impact of ICT on teaching have shown the require for unused pedagogies to cater for the energetic and chaotic learning that take place effectively as students control their own learning in zones of need and interest, as seen in New Zealand inquire about student learning in the arts (Holland \& O'Connor, 2004). ICT as a whole in education considers note, the requirements for instructors to be given with proficient support to coordinated ICT into programs of learning - especially with regards to technical, practical, educational, framework, and school administration viewpoints.

Inquire about by the Education Review Office (2005) in New Zealand has appeared that ICT use in schools is not equal and low in arts classrooms compared with other learning regions. Obstructions recognized by research participants incorporate the need of dependable internet access, and inadequately professional and specialized support to insert ICT into programs of learning, not fair as devices, but as arranged opportunities to progress engagement and accomplishment. In some research countries including New Zealand, there is not enough information on the impact of ICT has in the art praxis. One study on the Assessment of Arts Professional Advancement Online in Support of the Arts in the New Zealand Curriculum (Turnbull, 2002), reports briefly that the professional materials online and online facilitator support given by the Arts Online site (Education Ministry) improved arts planning and classroom practice, and thus results for students. No other research work is accessible on the influence professional support for arts instruction has in the New Zealand settings - in either educational or in community settings. The Arts Online proceeds to supply online support for arts educators in all divisions by giving discipline-specific interactive reservists, units and lessons, resources and site links, professional readings, occasions and community links, interactive arranging, newsletters and encouraged individual subject back (Dunmill and Arslanagic, 2006). 
This research work has reviewed important literature that examines the impacts of ICT interventions on results of student learning and has highlighted the challenges that ruin complete assessment of such interventions. Assessment is a pivotal process to evaluate how and when to use ICTs to accomplish wanted results and to what degree perception and reality adjust. However, the observed number of dependable and methodologically thorough studies that have been done on the impacts of ICTs in educational settings inside developing nations is little. From this little pool, this review proposes that the impacts of ICTs on learner results change, whether positive, negative, or no effect at all. The perception of ICT impacts however among stakeholders is generally positive and whether ICTs can meet these desires is dependent upon how such arrangements are executed.

\subsection{RESEARCH METHODOLOGY}

This part of the paper delved into the methodology and approaches that was employed in the study.

\subsection{Research Design}

The research work is purely qualitative. It involved soliciting information from respondents on the use of ICT and any ICT tool in the district understudy. The study is very much concerned with getting detailed views from Respondents. The key thought behind the qualitative inquiry is to study almost the issue or issue from respondents and to address the research to obtain the needed information, Cresswell (2009). Basically, the case study approach was used. This also implies exploring and getting to understand the meaning individuals or groups is assigned to inhuman or social problems.

\subsection{Location}

The study was conducted in the Eastern region of Ghana, New Juaben municipal as the area is: easily available; More specifically, the New Juaben District which forms part of the Eastern Region of Ghana. The abovementioned district covers an assessed area of 110 square kilometers measuring $0.57 \%$ of the total land area of the region. An overwhelming natural highlight in the region is the 'Obuo Tabri' Mountain found in Koforidua, which is considered sacred. Not too far from the renowned mountain is Akosombo Dam which holds Lake Volta, the biggest man-made lake in the world. Some well-known Waterfalls found in the area such as Akan Falls and Boti Falls and the Umbrella Rock pull in visitors to New-Juaben Municipal and Eastern Region.

Figure 4. Map of New Juaben Municipal

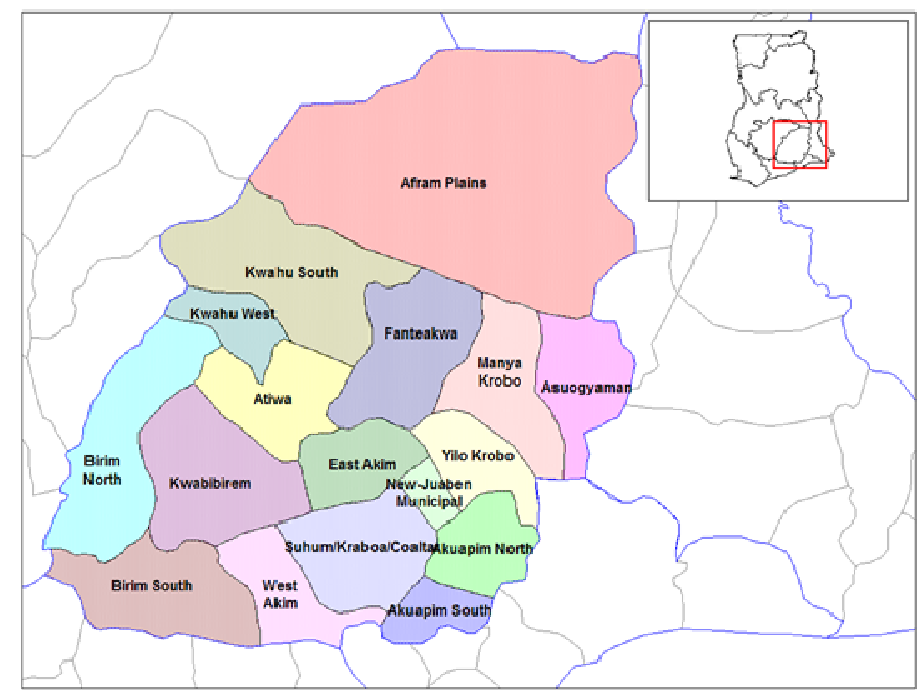

\subsection{Participants}

Members chosen for this study was based on a methodology referred to as, "purposeful selection" which, by one definition (Maxwell, 2005), indicates that "a choice procedure in which specific settings, persons or exercises are chosen intentionally to help supply data that can't be gotten as well from other choices" (p. 88). The selection of administrators for an interview for this research was purposeful, in that they were the pioneers of their respective schools and would get it best the process utilized inside the buildings with regards to ICT utilization by students. To accomplish a thick, wealthy description for the case (Esterberg, 2002) (Merriam, 2002), it was vital to incorporate different administrators from within the school area. One administrator from each school will be chosen, for a total of number fifteen participants to be met. Besides a few of the students will also be chosen and interview them on the advantage they have had from the introduction of ICT. 


\subsection{Data Collection}

The method of data collection used in this study was an interview. The interview focused on the questions of the research: What roles does ICT play in high school education in Ghana? What are the challenges faced by schools in the ICT integration process? What are the challenges faced by administrators in implementing ICT in government high schools in Ghana? What effects have ICT on education in government high schools in Ghana? The interviews aim to strengthen the validity of the findings from the questionnaire, as per the strengths associated with triangulation (as described earlier in the research). In the Interviews, the teachers can speak freely and express in their own way and this helps them to speak without any restrictions -this offers the researcher high credibility during the time of teacher's interview. In the interview, the researcher can get into more details with the teachers and expands the discussion to them. Here, it was believed that interviews with policymakers within the schools setting/the Education Ministry would pave the way for greater probing of the answers provided and would allow for answers which are free from the confines of policy or political ${ }^{\text {ee }}$ bias.

\subsection{Interview Design}

The interview involved a semi-structured interview with open-ended questions in giving room for more flexibility for both the researcher to ask extra questions and for the participant to offer more information (Kvale \& Brinkmann 2009). The interview was designed as it was open questions to provide more flexibility in order for the researcher to ask additional questions when needed and the method of design of questions helps teachers to more assist the researcher with more information. The researcher asked teachers to talk about their general views on the utilization of technology in education. The interview questions were derived from the study questions.

\subsection{Implementation of the Interviews}

The interview was conducted for administrators, teachers, school authorities and some students since they are the victims affected. A sample of administrators from the district education office was selected and interviewed on ICT's implementation in the education policy.

A sample representing staff members were selected for the interview. The sample contained members of teaching staff with varying experience in teaching, expertise in ICT, attitudes to ICT usage, responsibility within the school and gender were presented in a table. Teachers of various subjects represented include Art, business studies, English, geography, ICT, mathematics, Contemporary Foreign Languages (MFL), music, RE, PE, SEN and science. A timetable was set for interviewing. The researcher used a tape recorder to take records of the interviews. Definition of topics that were addressed in the course of the interview and before the interview for two reasons to: reduce anxiety among interviewees before the interview is started, and give time to participants to think about the interview subjects in order for them to provide answers that are realistic.

\subsection{Interview Procedure}

Sixteen (16) interviews were conducted in totality. The researcher interviewed 14 teachers, four Mathematics teachers, four Science teachers, four Arabic teachers and two English teachers. Two policy makers from the Ministry of education were also interviewed by the researcher. All recordings of the interview were done via tape recorder and transcribed to the English. Each and every interview lasted between 35 and 45 minutes.

\subsection{Validity and Reliability}

The report was peer-reviewed as a way of validating its contents. To validate the research instruments the researcher checked if there were any form of ambiguity or confusing terms so as to improve the validity content of the instruments. For the clarity and significance of the of the research instruments the test- retest technique was used. The instruments were tested in four schools and then re-tested after a week in the same schools which were not chosen for the study.

\subsection{Data Analysis Method}

Data collected was stored on a personal desktop computer. The data was first organized according to a data type for easy retrieval. Sub-folders were indexed according to date, interviewee profiles, document type or authors. A transcriber was engaged to assist with the part of the transcribing work. These audio snippets and templates were uploaded to a password-enabled site for the transcriber to download. All transcribed works were cross-checked by me against the audiotapes to ensure factual accuracy.

\subsection{Research Ethics}

To ensure that the study was conducted in an ethical way, extra attention was given to culture so as to be "sensitive to the socio-political contexts in which individuals live out their lives" (Busher \& James, 2007, p109); avoided detachment during fieldwork and be conscious of the possible harm I might be causing to the entire environment; engaged in responsive communication during reporting and to act responsibly when making public 
of what had been learnt (Flinders, 1992). Other more generic concerns of ethical issues include maintaining the privacy, anonymity and confidentiality of respondents as well as giving them the liberty to withdraw from the research at any point in time. I also strive to maintain the respondent's confidentiality by using pseudonyms for the school and interview subjects. All respondents were also shortly informed of their rights.

\subsection{ANALYSIS OF RESULTS}

\subsection{Findings and Discussions on ICT's in Senior High School in New Juaben Municipal}

The new coming of the idea in education, helping lifelong learning and providing alternative approaches in bringing quality education has been an important goal of the Government Education Policy Review report of 2004 which is still part of the present policy. In order to progress the quality of education, increase coverage and make high school education system responsive to the needs of the county and society, the National ICT for Accelerated Development policy (ICT4AD) (2004) and the education policy (2008) of the country have emphasized the integration of ICT focusing on high school education. In response to the Policies goals, the Government through the higher institutions has embarked on promoting electronic education in the educational system and also providing facilities for the enhancement of the policy in the country. This initiative is seen as critical towards achieving the educational provisions in the country. Supported with digital education, and quite a number of people from rural parts of the country can have access to Higher Education through e-learning mode (Col, 2004) This part of the work deliberated on the general knowledge of what constitutes digital education, the role it plays, challenges and effects in the provision ICT in the high school level of education.

\subsection{Background of the Schools}

School one is located in the koforidua township, it was set up within the year 1967 by then head of state Dr. Kwame Nkrumah. The school was known to be a Boys School since its foundation, until lately few young ladies were added to around 5\% of the total student's population. The school had over 2,200 understudies as at December 2011. The number expanded much inside the time-period of the 4-year tutoring program that was presented by the GES of Ghana. Sec-Tech has over 120 dynamic instructors and almost 90 non-teaching staffs who are devoted in giving the finest accessible administrations to their understudies. The school has the largest land in Koforidua, if not the whole of Eastern Region. The school hold most of the sporting events because of its size and its spacious environment.

School two is located is located at Effiduase, Koforidua. Bishop Joseph Oliver Bowers SVD established this school in the year 1958 as a Catholic seminary for boys who wanted to become priests. The population of the students' amount to over 2100 boys. Father Fredrischs, the second Headmaster, with the approval of Bishop Bowers, applied for incorporation into the Public Education System of the Ministry of Education of Ghana due to the huge cost of operating the school. On 1 September 1968, St. John Seminary and College were immersed into the Ghana Education Service of the Ministry of Education (Ghana) as a government assisted secondary school. The name was changed from a seminary to become a public high school in that year. The 2007 Ghana education restructuring which was done by the John Kufuor administration saw the school re-designated Pope John Senior High School and Minor Seminary. The school owns a boarding facility to accommodate its students who comes from afar. As at now, the school has professional teaching staffs which amount to 92 and 85 nonteaching staff. Currently, 100 seminarians and 2000 boarding students present now. Pope John Secondary School has now climbed up to be one of the best schools in Ghana in terms of academics, sport, discipline, music etc.

School three was set up by Mr. Fred Addae and Mr. Francis Adjei Tetebo in 1943 with a starting populace of 16 boys called Phoenix College in a private transitory structure. An increase in student population facilitated the development of the school to a new area which currently houses the Normal Technical Institute in Koforidua at the year 1950. The school have now moved to Effiduase as its present premise which was made likely by the effort of Rev. Mr WT Wutor a temporary worker, Dr. Nimako, the first MP for New Juaben Constituency, and Nana Frempong Mposo II, the then chief of Effiduase. The name of the school was changed from Christ College to Ghana Secondary School in the year Ghana gained independence by Osagyefo Dr. Kwame Nkrumah on his visit to koforidua. The school now has a number of over 2300 (females and males) with 80 well qualified and trained staff population.

School four was established in 1953 as New Juaben College of Commerce (NJUACOCO), by Mr. G. Kwaku Adjei who is a native of Asokore, near Koforidua in the Eastern Region, as a private school, and renamed to New Juaben Secondary Commercial School (NJUASCO) after it's conversion to a government-aided secondary school in the year 1965, has built extraordinary achievements. The school provides an on-campus accommodation facility for both students and teachers. The school has a population of about 2600 students and teachers also amount to 192 which includes both teaching and non-teaching staffs. The school is well noted in the district based on it's well performance in sporting activities.

School five, the Asokore-Koforidua Seventh-Day Adventist Senior High School in the New Juaben Municipality of the Eastern Region, notwithstanding its numerous challenges. Mr. Francis Kobina Kra-Mensah 
is the acting headmaster of the school.it was founded in the year 2000/2001, as a private school with a total number of about 280 boys and girls, with backing of the then West Africa Union of the SDA Church, the Municipal Assembly, the then SDA Training College, and some humanitarians from the USA. The school is made up of 42 teaching and 38 non-teaching, are not placed on the payroll which all sums up to 80 , but contribute massively towards the progress of the country for its love.

\subsection{Results of the Interview}

In a broad-spectrum, ICTs integration in education is not new to all the respondents, almost all have some fair idea. Most of the respondents made it clear that ICTs learning call for the introduction of contemporary communication equipment to introduce teaching and learning in classroom. Through the interview it was noticed that two-thirds of the respondents narrowed ICTs implements to computer and Internets. Whiles the third respondents listed other technological tools like television, radio, video, audio among others as media in diffusing teaching and learning in schools.

\subsection{The Implementation ICT in High School Education in Ghana}

On the role that ICT plays in education, the respondents were asked if ICT has been added to the instruction of non-ICT courses and all of the respondents indicated no to the questions. They also indicated through a followup question that the ICT integration in all the classrooms has its own issues and challenges that led to the school building an ICT lab for the ICT courses. The respondents stated that ICT in education could make teaching and learning easier and faster, others also stated that one of the roles of ICT integration in education is to enhance the scope of the students through its learning process. In one of the schools, the respondents specified that the role of ICT in our modern education is very essential that it enlightens and allows students to become more abreast with time I this fast-moving technological world. The ICT teachers in the schools indicated that their lessons have been great with the use of ICT and he wishes it could be integrated into all the other course so that all the other teachers can also use ICT facilities in teachers just like teaching the ICT course. The researcher observed that 4 of the schools selected have websites. However, they were not fully functional to meet the 21 st century ICT websites that teach the students outside the school. The leadership of the schools informed the researcher that efforts are being made to upgrade the website so that both teachers and students can receive a maximum benefit from it. Respondents from most of the schools also stated that the websites could enable access to information on new updates pertaining to the school for both students and staff and provides an opportunity to advertise the school to the outside world and promotes its branding.

All the respondents specified that ICT could not be ignored in modern-day teaching. However, they also indicated that the ICT for development policy needs to be modified to give a clear direction to both the senior high schools and other schools as to how the implementation should take place and who and who are responsible to financing the policy implementation process within the senior high schools.

"The Education Ministry is talking about the introduction of ICT in schools. But we do not see how it's implementation is going" (The Administrator - Ghana Senior High Technical School, New Juaben District).

"The Ministry of Education is a bit relaxed in its implementation of ICT policies in senior High schools" (The administrator - New Juaben Commercial School)

\subsection{Effect of ICT on Education in Government High Schools in Ghana}

The responses given to the researcher indicated that ICT is necessary for teaching and learning of the entire courses in their schools. They explained further that students become abreast and more equipped in the technological world after graduation. Moreover, some students end up making a profession out of ICT through its learning process. The effect of ICT in education was highly emphasized by all the respondents as they indicated that it enhances easy access to information.

A respondent also indicated that implementing ICT in education policy has a negative effect on government high schools in Ghana. He explained further that some of the negative effects include an inattentive nature of students when teaching is ongoing. He stressed on it that when students have iPhone, iPads and or iPods, they tend to use it in class when the teaching is teaching and that can distract the class sometimes. However, it came up during the interview that government needs to provide sufficient supply of ICT logistics to enhance easy access by students to boost the learning process. They recommended that training and employment of more IT personnel for High School education should be encouraged. They also suggested that creation of awareness by government on the importance of ICT training and learning process in High Schools is very important and should be a priority of the government so that he can entice stockholders to invest in the public education in the area of ICT. Among all the schools, respondents were very optimistic that ICT has a very positive effect on government senior high schools in Ghana.

"ICTs integration in my school is facilitating the teachers to record grades of the students, and also used to track the performances of students by the administration" (The head teacher-POJOSS, Koforidua) 


\subsection{Challenges Faced by Schools in the Integrating of ICT}

The challenges faced by the senior high school in Ghana pertaining to the implementation of ICT in education where outlined by the respondents from all the schools studied as follows: Inadequate ICT logistics for training and learning process; students access to computers for more practical work after tuition and demonstration; inadequate IT personnel to boost the level of teaching and learning process; poor infrastructure to support the needed ICT logistics; poor maintenance culture for the existing ICT logistics; and inadequate finance to support and employ more qualified ICT inclined teachers into the various senior high schools.

All the respondents also indicated yes to an interview question posed by the researcher who wanted to find out if the school motivates students to use logistics for learning to help them developed their ICT skills outside the school curriculum. They further emphasized that the current student's skills in ICT can be rated on a scale of 4 out of 10, which implies a low level of ICT skills in this modern era. The teachers were also asked how many times they upgrade their ICT skills and all of them said one in every year. They gave a reason that it is neither a requirement by the schools or the government for them to upgrade their ICT skill making them bears the entire cost of their ICT training. "This is why many of the teachers don't bother to obtain the ICT training at all, the cost is too much compare to the teachers' pay" as indicated by one of the respondents. The respondents suggested that to improve students' ICT skills, the schools should play a role of providing easy access to ICT logistics, encouraging them on the use of computers and the internet and ensuring that the students have constant practicel and familiarization with computers.

\subsection{Challenges Faced by Administrators in Implementing ICT in Government High Schools}

Administrators from the various senior high schools also shared their view on the challenges they face in implementing the ICT4AD policy in their respective schools. All of the respondents indicated agreed that there were challenges being faced by the administrators when they responded yes to a question posed by the researcher to find out if the respondent thinks government high school faces some challenges in implementing ICT in their education in Ghana. They attributed the challenges to the insufficient supply of logistics and computers by government for training and learning of ICT, poor maintenance of few available logistics for the learning of ICT, students' inability to easily grasp certain of the whole new concepts of ICT in the education curriculum, financial and other bureaucratic systems that courses unnecessary delays in the implementation process. Aside all the challenges, an administrator from one of the schools commented that the introduction of ICT had increased the quality of learning in the senior high schools where the policy in properly being implemented. He supported his response by saying that "Yes, it has made teaching and learning easier and faster through proper demonstration in teaching activities and it has also encouraged students more in the basic use of the internet. Teachers are now able to easily assess students' performances through its introduction". Many of the respondents also shared the same idea with the administrator and believe that the government needs to take the ICT in education policy seriously, overcome the challenges and enforce its implementation to enhance education in Ghana.

Table 1. ICT Equipment used in the Selected Schools

\begin{tabular}{|l|l|l|l|l|l|l|l|l|l|l|}
\hline & \multicolumn{2}{l|}{ KSTS } & \multicolumn{2}{l|}{ POJOSS } & GHANASS & \multicolumn{2}{l|}{ NJUASCO } & \multicolumn{2}{l|}{ SEDASS } \\
\hline $\begin{array}{l}\text { Availability of ICT } \\
\text { equipment }\end{array}$ & Avail. & $\begin{array}{l}\text { Not } \\
\text { avail. }\end{array}$ & Avail. & $\begin{array}{l}\text { Not } \\
\text { avail. }\end{array}$ & Avail. & $\begin{array}{l}\text { Not } \\
\text { avail. }\end{array}$ & Avail. & $\begin{array}{l}\text { Not } \\
\text { avail. }\end{array}$ & Avail. & $\begin{array}{l}\text { Not } \\
\text { avail. }\end{array}$ \\
\hline $\begin{array}{l}\text { Photocopier } \\
\text { machines }\end{array}$ & 2 & & 1 & & 2 & & 3 & & 2 & \\
\hline $\begin{array}{l}\text { Laptop/Desktop } \\
\text { Computer }\end{array}$ & 49 & & 51 & & 50 & & 40 & & 25 & \\
\hline Data Projector & 1 & & 2 & & 2 & & 1 & & & 0 \\
\hline $\begin{array}{l}\text { Interactive } \\
\text { Whiteboard }\end{array}$ & & 0 & & 0 & & 0 & & 0 & & 0 \\
\hline Word Processing & Yes & & yes & & yes & & yes & & yes & \\
\hline Internet & Yes & & yes & & yes & & yes & & yes & \\
\hline Digital Camera & & no & yes & & yes & & yes & & & no \\
\hline TV & Yes & & yes & & yes & & yes & & yes & \\
\hline CD/DVD player & & & & & & & & & & \\
\hline Radio & Yes & & yes & & yes & & yes & & yes & \\
\hline $\begin{array}{l}\text { Any other form of } \\
\text { ICT equipment }\end{array}$ & & no & & No & & no & & no & & no \\
\hline & & & & & & & & & & \\
\hline
\end{tabular}

Based on the interview conducted some equipment like computers, projectors and photocopier machines are available in the said schools. Comparing the number of computers in the school it is limited for all the students to get access. Students share computers and make it difficult for them when learning. Teacher exposure to ICT 
usage. The extent to which the teachers are exposed to the use of ICT facilities in secondary schools. The research illustrated that only $35.5 \%$ of teachers use the internet to search for teaching materials, while about $20.8 \%$ of them admitted that they had been trained in ICT related course which they integrate into their teaching and learning. A greater portion of the respondents also agreed that they had a basic idea of the use of ICT equipment. Of the respondents, 39\% agreed that teachers use internet and email in teaching and learning processes, while some also admitted that they are using spreadsheets, word processors, databases and desktop publishing, respectively. On the average few of the respondents agreed that teachers were exposed to the use of ICT. Such results imply that teachers are less exposed to the use of ICT.

Upon all that have been collected form the respondents it was brought to light ICT facilities such as computer laboratories, e-books, internet, projectors, electronic boards and computers were not available in secondary schools in New-Juaben municipality. This maybe as a result of the government and other stakeholders not putting enough funds in the provision of ICT equipment. The study also revealed that teachers were exposed to the use of ICT but lack of these facilities restrict them from passing it on to the students. Since there is no modern ICT equipment to facilitate teaching, teachers are stick to the old method of chalk and talk, the practice which makes them to be behind the world of ICT.

All the five school have some form of Internet access. Out of the five schools, one had a satellite dish, the other 4 had Digital Subscriber Line (DSL). Most of the schools' own computers but are slow, only three of the schools have high-speed computers (Pentium 4). The other two schools have slow paced computers and most of these computers were not in good shape. It is significance seeing that the accessibility of internet connection is essential for the achievement of teaching and learning, principally its centerpiece of online collaboration. Schools that have adequate and modern technology infrastructure and reliable internet access make successful results in terms of teaching, learning and administrative purposes. The schools that have the ICTs infrastructure for example were able to the facilities to promote research, learning and data management. Furthermore, it was revealed that the most perceived constraints of using ICT in schools is the fact that many teachers don't get support from school, municipal, ministry or any other government body. Therefore, support from school, municipal, ministry or any other government body is the major challenge facing the application of ICT in secondary schools in New-Juaben municipality. This is attributed to low level of funding in the school system from stakeholders. If schools are well funded, the management of the school can always make arrangements for ICT practices

\subsection{DISCUSSIONS AND SUMMARY OF THE FINDINGS \\ 5.1 Teachers Training and Local Support}

Based on the first research question, there was no substantial evidence to suggest that teachers' access to computers would robotically be followed by an increase in the skills and capabilities to use them in teaching and learning. However, most of the some of the school indicated that they have teachers who have developed basic skills in ICT. This was supported by literature from Australia by Newhouse (2002), and the United Kingdom(UK) by Loveless (2002) there is a need for teachers to be self-assured in their subject knowledge as well as little ICT literacies so that they can successfully blend ICT into teaching programs. On the problem of monetary challenges, the respondents the researcher determined that as per the gov't policies to enhance the standard of education, monetary aids got to varied schools in every district together with agencies. however, no survey was done and no verification created by government groups to understand whether technical instrumentation reached the schools or not. it absolutely was noticed that there are colleges once receiving technical instrumentation also not used equipment efficiently because of negligence and untrustworthiness equipment wasn't fitted and not given to succeed in target mounted by the govt. it was found that lack of coaching and lack of technical information creating teachers tough to make use of the given equipment and thereby inflicting forceful down fall in the quality education has contributed tremendously to the compounding challenges. In various government schools it was observed that few periods were allotted for teaching computer education. Some head teachers of the schools giving less importance to computer education and makes ICT studies less attractive for studies.

Some of the teachers said they did not have the skills to use computers to improve their teaching and learning, the educators said that they could learn how to use ICT and adapt to current technological advancement if these ICTs were available at their schools. It therefore appears that the educators blamed the absence or limited availability of the ICTs at schools for their lack of knowledge and confidence in using ICTs for teaching and learning.

\subsection{ICT Implementation}

The second research question also come up with some basic problem associated with the head of institutions which do not know how to make use of computer technology for making understanding the other subjects. They don't know making use of the tools for teaching different subjects. It is clear in different visits that head masters 
of the schools still showing passion towards traditional education methods thereby not showing any interest to ICT utilization. There's no perception from the government authorities how the computer instruction was actualized in schools. No verification was made on syllabus framed for teaching.

District education authorities displaying abandonment in visiting schools to brings the setbacks and gathering response about ICT use in most of the time fail to do so. For observation of ICT utilization, the government has decided to employ extra staff specifically observing infrastructure and syllabus and marks. But the decision is still not set. It was established that absence of internet facility causing vast communication gap and becoming a barrier to ICT implementation.

Reputed agencies that undertake the responsibilities of making infrastructure in faculties need to train a minimum of 5 teachers as well as head master once a year. However, this wasn't enforced by the agencies and no management and no penalty from the gov't authorities.

\subsection{Students Impacts on the Use of ICT}

The third research question paints that these days the part of Information and Communication Technology (ICT), especially internet within the education division plays a significant part, particularly within the prepare of enabling the technology into the instructive exercises. Education sector can be the utmost operative sector to anticipate and eradicate the undesirable impact of ICT. Technology on another side can be the most operative way to increase the student's knowledge.

Being watchful of the significant role of ICT (internet) in our life, specifically in the educational activities, education authorities should be prudent enough in implementing the actions to authorize ICT in aiding the teaching and learning method in the classroom. ICT isn't fair the bloom of the instructive activities, but also, it'll be the secondary alternative to progress the successful and significant instructive process.

In Ghana's education framework and educational programs subject introduction and circle transferring of information and unilateral and non-active strategies in education has been kept up more or less and considers within the educational modules of the system show the system is totally centered on designing and producing the same curriculum for all students (Shahmir, 2011). Centralization causes the capacity of arranging and administration of the process of learning that are the most aptitudes within the application of technology not to grow in individuals, in addition to centralization, all exercises and instructive computer program are being created by the government and this prevents the growth and development of the private sector in this field. While if the effective application of information technology in education is the dynamic support of the private segment (M. Ghaffari 2008). Making strides the quality of education and training may be a basic issue, especially at a time of educational extension. ICTs can boost the superiority of education in numerous methods: by engagement and increasing learner motivation, by aiding the attainment of basic talents, and also enriching teacher through training. ICTs are moreover transformational devices which, when utilized suitably, can advance the move to a learner-centered environment (Tinio, 2003). Numerous studies on ICT integration discover that ventures drop brief of expectations since the teachers proceed working inside a conventional vision of routine learning (Livingstone 2012). Teachers need to believe that new ways of teaching are effective and will make a variance for their students in order for them to continue using new approaches. Teachers' being thoughtful and dedicated are mainly significant to endure changes in areas such as project-based learning or student-centered techniques, which require basic variations to a teacher's instructional practice (Samuelowicz K, 2001). Understanding how technology turns into the intricate realisms of classrooms a serious factor in has been making actual change in schools in the developed nations (Mumtaz, 2000). Yet minute has been brought to light about educational technology projects in the classrooms of this developing country.

\subsection{ICT Outcomes on Students}

The fourth research question also came up that the orthodox teaching-learning methods are experiencing a structural change. The focus of instruction is now on education programs/practices that promote competency and performance. Such curricula tend to require access to variety of information sources, information forms and types; student-centered learning settings based on information access and inquiry; learning environments centered or problem-centered and inquiry-based activities, authentic settings and examples; and teachers as coaches and mentors rather than content experts (Mondal A, 2012). The change towards development of educational packages is well reinforced by and stimulated by the initial instructional technologies within the classroom setting which creates a positive effect in the modern-day teaching and learning. This theme also sought to examine teachers' perceptions of the contribution of ICT use to the learning experiences of the students. Teachers responses were grouped into four sub-categories particularly facilitates construct building, improves recall and understanding, provides a lot of purposeful learning experiences and harmful effects for student learning.

\subsubsection{Enables Concept Building}

Teachers reported that the utilization of ICT in their teaching makes it easier for college kids to visual and 
perceive ideas. ... what I do is use photos or if I can get a video thus it's easier for college kids to visual... it's easier for them to know it if they can truly see it. They also expressed the idea that the utilization of ICT not solely brings subject content to life for the scholars but additionally permits them to envision the practical, everyday application of ideas and helps them to place things into context.

\subsubsection{Improves Recall and Comprehension}

All instructors were of the opinion that the employment of ICT facilitates better pupil understanding of thought being tutored because it shuffles it easier for college kids to follow what's being delivered. So, it's easier for a few students to examine something, it's easier for them to compass it if they'll truly see it. I tend to like to use it to assist them to grasp higher. Additionally, ICT makes attainable the employment of concrete, globe representative that facilitates higher recollection of content tutored. I tone they'll better recall examples I provide because whenever, I'm talking about a right they keep in thinker I showed them something on Tiananmen sq. and security review and that they can relate teacher conjointly expressed the read that the employment of ICTs fosters a liveliness of enquiry in students because it gets them mentation and encourages them to salary increase queries

\subsubsection{Digital Education}

Teachers felt that the utilization of ICT affords experiences that build learning additional relevant and real for the students. Subjects awaken as students are opened to fifty-four Teachers' opinions of the role of ICT in teaching of recent Studies reviewed examples that they can relate. ICT use also helps to produce sensitive problems to life for the student, rather than merely hearing the teacher name problems they can see visual representations of what's being mentioned. I teach mass media and you talking regarding the news and the way sometimes they raid people's privacy or things that don't seem to be acceptable. and often simply tell them regarding however I found the image last night after I was looking through and was like definitely wish to use that to indicate them... teachers additionally report that with the utilization of ICT students take responsibility for his or her learning which there's larger possession of learning. I really have situations where children actually ask me miss what's the next topic if they could prepare something related. When they have to create something I think because they have the computers they are eager to learn more from it. When such thing happens then learning is not only seen/done in the classroom only.

\subsubsection{Destructive Outcomes for Students' Learning}

Even though teachers trust that almost half the integration of ICT had constructive results for college students learning, they also uttered the concern that ICT use could have several bad significances for students ${ }^{\text {ee }}$ learning. attributable to persistent use of ICT within the school, students are developing growing dependency fifty-five. Teachers' perceptions of the impact of ICT to the teaching of recent Studies on ICT. The expectancy is that everyone lessons will be delivered with it and once it's not present student lose attention and interest. So, once you actually have a distinct variety of lesson or a lesson and you don't use the ICT it becomes bored.... Sometimes if you don't use it enough they will become even disruptive because they don't have that emphasis that they're familiarized. additionally, ICT use will be a supply of disturbance for a few students. Unless rigorously monitored they'll get held within the technology and lose vision of the aim of the exercise. Also, they'll become too enthusiastic and unsettled once technology is employed. Your lower school would tend to urge to be happy with the technology and it may become a lot of amusement than education and you pay heaps of your time making an attempt to zone them back in. One teacher expressed the opinion that mistreatment ICT to boost learning doesn't principally work for all students. Some students still show a scarcity of understanding even once technology is employed. There are students' even if the ICT is used they might still return after the class or outside the class and say Miss I actually didn't understand... In addition, teachers noted with concern a tendency by students to view only what is presented to them on the screen as important. Though they participate in class discussion, they tend to dismiss this as unimportant and, therefore, there is little recall of what was discussed after class. 56 Teachers' insights of the contribution of ICT to the teaching of Modern Studies. They just pay attention to the PowerPoint. They don't take notes in class but they're focused on what's happening in the PowerPoint and what's being deliberated on in class. But after class if you ask them on something that was presented in class but wasn't spelt out in PowerPoint they won't remember. All teachers expressed the priority that ICT use changed into ensuing in a lack of interest in analyzing. students typically explicit the choice to take a look at the DVD rather than examine an e-book. They don't realize the way to study...even for literature in forms 4 and five they hire the film on DVD... so they have lost the art of reading the book which continues to be very essential for their tertiary studying. further, vital competencies which can be required in higher schooling, which includes research abilities, formal writing competencies and skills of evaluation and synthesis are being misplaced. The reality that they might be losing greater of their writing capabilities... So even in writing presentations they could type and count on the pc to discover spelling mistakes... So, they're no longer getting to know as properly the approach of writing a multiplied essay or writing an improved response. the difficulty of plagiarism became additionally recognized by means of teachers as an area of specific difficulty particularly with respect to internet use. instructors commented that students had 
been starting to increase a „cut and paste ${ }^{e e}$ mentality. we have troubles with plagiarism all of the time. They love to reduce and paste. They nevertheless don't recognize a way to summarize. The hassle, however, became greater commonplace with the lower school.

\subsection{CONCLUSION AND RECOMMENDATIONS 6.1 Conclusions}

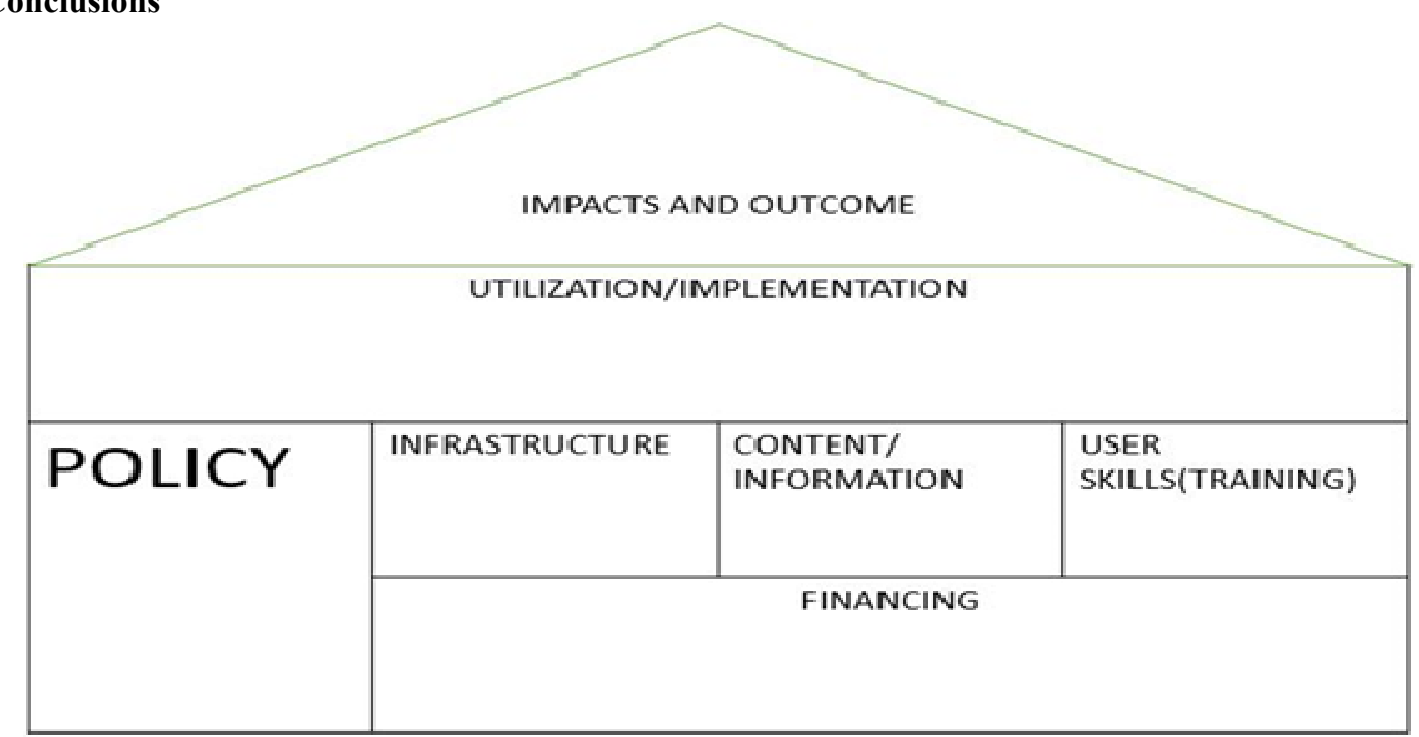

The figure above shows how ICT integration can reach is reached its goals after schools uses ICT by supported by infrastructure and application existence, operated by user whose ICT professionals. For the policy to be implemented successfully some components such as trained expertise, infrastructure (computers, projectors and so on) and content needs to be available. With reference to the data collected in the fourth chapter most of the schools in the municipality lack some basic ICT equipment such as photocopiers, internet, interactive whiteboard and other, making it tough for the policy to be carried on. Since ICT needs a lot of practical's, teaching without the availability of these equipment make its teaching and learning difficult. Users of the policy have to obtain some skills, which should be from the administrators to the teachers of the various schools. These skills should not only be known by the ICT coordinators but all the teachers in the school. Because when all this ICT equipment are installed in the various classrooms, it will call for usage by all the teachers irrespective of your subject. Teachers needs to be trained on how to use ICT to enable a successful implementation of the policy.

Also, the content of the policy has to be spelt out clearly for the understanding of its implementers, there should be regular checking by the authorities to check the strength of the policy.

Lastly, before all these can go on it need financial backing from the government to make a successful implementation. The Policy is a supported component since the weight is not significant, it means that policy is not considered as a primary key in order to utilize ICT in education. The study concludes that progress of ICT integration framework should ponder on components contribution weights among the mechanisms that can be used to control the implementation of ICT adoption in education.

Based on the findings of the studies it was concluded that there have been some of demanding situations dealing with effective implementation of ICT in colleges in New Juaben District. these demanding situations blanketed: few computers and computer labs, inadequate internet connectivity, electricity unreliability and absence of sufficient system inclusive of liquid crystal display projectors, audio system amongst others to enhance powerful implementation. The study additionally concluded that efforts with the aid of the ministry to maintain ICT implementation initiatives in colleges are very minimum specifically within the rural districts. Similarly, the study also concluded that despite the fact that there are few ICT professionals available there whiles there a number of instructors who're computer literate.

Majority of teachers had access to the internet in their schools but unfortunately, they hardly used it because of lack of some basic knowledge on the use of computers. The few who used it frequently used it for their individual growth. Greater number of schools had ICT but have inadequate funds to support the implementation of ICT. The main mode of implementation of ICT policy in schools was by offering separate computer courses with a third of the schools using the internet in teaching specific subjects such as ICT, mathematics, geography etc., but due to the lack of computers and other ICT equipment to facilitate the program its objectives have not been achieved. For the policy about the use of ICTs in school to be successful, there is the need to consider the recommendations listed above. 


\subsection{Recommendations}

It is recommended that ICT infrastructures should be provided to the Senior High Schools for effective teaching and learning process since it is the basic stage of equipping the youth with the necessary skills and knowledge for national development. Teachers should be given the necessary training in ICT usage so that they become familiar with the modern pedagogy of imparting knowledge and skills, and possibly become part of the curriculum structure for their professional training. Governments ought to move forward the training of principals, teachers and computer staff on the utilize of computers and other ICT tools through seminars, workshops and in-service training.

Again, the national and county governments should show more interest in imbibing information communication and technology (ICT) and supply the necessary ICT equipment to all secondary schools through improved funding for the acquisition of ICT equipment. Modern ICT laboratories should be built for our Senior High Schools to accommodate enough students at a time looking at their population size for effective and efficient teaching and learning atmosphere. There's the need for ICT offices in senior high schools to present browsing sessions in their computer research facilities for understudies. Measures should be taken to guarantee that students used the internet for educational purposes by monitoring them. School administrators should prepare budgets to support ICT implementation policies.

Emphasis should be aimed at developing a long-term program effective for continuous commitment to training and use of instructional technologies. Teachers and administrators must have clear and positive incentives for participating in ICT in-service. For example, the Ministry of Education (MOE) should provide such incentives as tuition for advanced college coursework (delivered on-site by satellite) or promotion in rank.

Also, it is recommended that Policy Formulators should be clear with the ICT policy and its direction of implementation with the necessary guidelines so that the implementation agents like Ghana Education Service, Ministry of Finance and the likes can help to make a reality since competency in ICT is the modern way of acquiring critical skills and knowledge effective and efficient economic development.

\subsection{Suggested Areas for Further Study}

i. The socio-economic factors that affect the uptake of e-learning in public secondary schools.

ii. The role of e-learning in preparation of adequate skilled manpower to speared the country towards the understanding of vision 2030.

iii. ICT adoption in educational institutions has brought gains and losses. A critical analysis of both the gains and losses arising from ICT adoption in institutions.

\section{REFERENCES}

[1] D. M. Watson. Pedagogy before Technology Re-Thinking the Relationship Between ICT and Teaching. Education and Information technologies, 2001,6(4):251-66.

[2] W. R Jordan, J. M. Follman. Using Technology to Improve Teaching and Learning. Hot Topics: Usable Research, 1993.

[3] J. Rubery, D. Grimshaw, J. Rubery. The Organization of Employment: An International Perspective. Basingstoke: Palgrave Macmillan, 2003, 223-231.

[4] L Victoria, V. L Tinio. ICT in Education. London: Macmillan, 2003: 200.

[5] V. L Tinio. Survey of Information \& Communication Technology Utilization in Philippine Public High Schools. http://www.fit-ed.org/downloads/ICT\%20Utilization\%20Survey.pdf, April 15, 2008.

[6] S. Noor-Ul-Amin. An Effective Use of ICT for Education and Learning by Drawing on Worldwide Knowledge, Research, and Experience. ICT as a Change Agent for Education, 2013,2(4):38-45.

[7] P. G Paris. Critical Thinking and the Use of the Internet as a Resource. International Education Journal, 2002 , 4(1):30-41.

[8] S. Isaacs. Transforming Education: The Power of ICT Policies. Unesco, 2011.

[9] A. Tella, O. M Toyobo, L.O Adika, et al. An Assessment of Secondary School Teachers Uses of ICT's: Implications for Further Development of ICT's Use in Nigerian Secondary Schools. TOJET. The Turkish Online Journal of Educational Technology, 2007,6(3), 3-5.

[10] S. E Aduwa-Ogiegbaen, E. O Iyamu. Using Information and Communication Technology in Secondary Schools in Nigeria: Problems and Prospects. Educational Technology \& Society, 2005, 8(1):104-12.

[11] The Ghana ICT for Accelerated Development (ICT4AD) Policy. The Republic of Ghana. http://www.moc.gov.gh/moc/PDFs/Ghana_ICT4AD_Policy.pdf 2003.

[12] Government of Ghana. Government of Ghana Ministerial ICT Policy Statement. NBS Multimedia, 2005.

[13] S. Kennewell, G. Beauchamp. The features of interactive whiteboards and their influence on learning[J]. Learning, Media and Technology, 2007, 32(3):227-41.

[14] E. Alharbi. A Study on the Use of ICT in Teaching in Secondary Schools in Kuwait. Kuwait: Cardiff School of Education, 2014, 1-263 
[15] Infectious Diseases Society of America (IDSA). Combating Antimicrobial Resistance: Policy Recommendations to Save Lives. Clinical Infectious Diseases, 2011, 1(5): 397-428.

[16] M. Considine, J. M Lewis. Governance at ground level: The Frontline Bureaucrat in the Age of Markets and Networks. Public Administration Review,1999, 1(5):467-80.

[17] S. A Snell, M. A Shadur, P. M Wright. Human Resources Strategy. The Era of Our Ways,2000, 1(7):1-39.

[18] P. Waller, R. M. Morris, D. Simpson. Understanding the Formulation and Development of Government Policy in the Context of FOI. London: London's Global University, 2008,3-108.

[19] T. Brush, K.D Glazewski, K.F Hew. Development of an Instrument to Measure Preservice Teachers' Technology Skills, Technology Beliefs, and Technology Barriers. Computers in the Schools, 2008, 25(12):25-112.

[20] C. Blurton. New Directions of ICT. Open Journal of Social Sciences,2002, 24(4):4-15.

[21] S. Reid. The Integration of Information and Communication Technology into Classroom Teaching. Alberta Journal of Educational Research, 2002, 1;48(1):30.

[22] E. UNESCO. International Standard Classification of Education-ISCED[R]. Paris, UNESCO, November 1997.

[23] C. Y Crenshaw. Teaching for Transformation: Engaging a Christian Worldview in Teacher Education Courses to Address K-12 Social Issues. USA, Baylor University,2013,1-292.

[24] E.M Rogers. Diffusion of Innovations. Simon and Schuster. New York, Free Press of Glencoe, 2010,1-134.

[25] E.M Rogers. Lessons for Guidelines from the Diffusion of Innovations. Joint Commission Journal on Quality and Patient Safety, 1995, 21(7):324-8.

[26] M. Crotty. The Foundations of Social Research. Meaning and Perspective in the Research process. Sage: Sage Publication, 1998 Oct 15, 1-256

[27] V. Venkatesh, M.G Morris, G.B Davis, et al. User Acceptance of Information Technology Toward a Unified View. MIS quarterly, 2003, 1(6):425-78.

[28] S. B Merriam. Qualitative Research and Case Study Applications in Education. Revised and Expanded from Case Study Research in Education.350 Sansome St, San Francisco, Jossey- Bass Publishers, CA 94104; 1998,1-127.

[29] E. Ackermann. Piaget's Constructivism, Papert's Constructionism. What's the Difference? Geneva, $2001 ; 5(3): 438$.

[30] T. Tchombe, M. Maiga, K. Toure, et al. Getting Ready for Higher Education. The Role of ICT in Secondary Schools. Biennial of the Association of Development of Education in Africa, 2008, 5(24):24-25.

[31] S. Gillard, D. Bailey, E. Nolan. Ten Reasons for IT Educators to be Early Adopters of IT Innovations[J]. Journal of Information Technology Education, 2008,1(7):21-33.

[32] E. Takyi-Amoako. Comparing power spaces: The Shaping of Ghana's Education Strategic Plan. Compare. A Journal of Comparative and International Education, 2012, 42(1):35-113.

[33] M. Oliver. Emancipatory research. A Vehicle for Social Transformation or Policy Development. In Inaugural NDA Disability Research Conference. Conference Proceedings, Using Emancipatory Methodologies in Disability Research, Dublin, 2002, (pp. 15-23).

[34] T. Tchombe. Education, Violence, Conflict and Prospect for Peace in Africa. An Evaluation of Research Endeavours for Peace Education. In Colloque International, 2006,5(23):1-25.

[35] S. Gillard, D. Bailey, E. Nolan. Ten Reasons for IT Educators to be Early Adopters of IT Innovations. Journal of Information Technology Education Research, 2008, 1(7):21-33.

[36] T. R Burns. The sociology of complex systems. An overview of actor-system-dynamics theory. World Futures, 2006, 62(6):40-411.

[37] W. B Hollow, D.G Patterson, P.M Olsen, et al. American Indians and Alaska Natives. How do they Find their Path to Medical School. Academic Medicine, 2006, 81(10): 9-65.

[38] C. Strigel, L Ariunaa, S Enkhjargal. Where desert meets technology. Findings from ICT in Education Initiatives in Rural Schools in Mongolia. Kuwait, Queens University of Technology Brisbane, 2007,1-327.

[39] J. Mulder. Knowledge dissemination in Sub-Saharan Africa. What Role for Open Educational Resources (OER). Amsterdam: University of Amsterdam. 2008,p14.

[40] M. Geldof. Earphones are not for Women. Gendered ICT Use Among Youths in Ethiopia and Malawi. Information Technologies \& International Development, 2011, 7(4):pp-69.

[41] P. Newhouse, S. Trinidad, B. Clarkson. Quality Teaching and Learning Practice with Information and Communications Technologies (ICT). A review of the literature,2006,4(32):1-12.

[42] S. Bramall, J. White. Will the new National Curriculum live up to its aims[J]? Impact, 2000, 2000(6),5-174.

[43] C. Holland, P O'Connor. " Like Writing Off the Paper". Report on Student Learning in the Arts. Report to the Ministry of Education, Holland, Ministry of Education,2004.

[44] W. Turnbull. The Place of Authenticity in Technology in the New Zealand Curriculum. International Journal of Technology and Design Education, 2002, 12(1),23-40. 
[45] M. Dunmill, A. Arslanagic. ICT in arts education. A literature review, New Zealand, University of Canterbury, 2006,5-167.

[46] J. W Creswell, W. Zhang. The Application of Mixed Methods Designs to Trauma Research. Journal of Traumatic Stress, 2009, 22(6):21-612.

[47] D. L Barkley. The value of case study research on rural entrepreneurship. Useful method Inpresented Joint ERS-RUPRI Conf., Exploring Rural Entrepreneurship, Imperatives Opportunities Res, Washington DC, 2006,1-17.

[48] M. D Fetters, L.A Curry, J.W Creswell. Achieving integration in mixed methods designs - principles and practices. Health services research, 2013, 6(2):56-2134.

[49] M. Q Patton. Two decades of developments in qualitative inquiry. A personal, experiential perspective. Qualitative social work, 2002,1(3):83-261.

[50] B. Kaplan, J.A Maxwell. Qualitative Research Methods for Evaluating Computer Information Systems. In Evaluating the Organizational Impact of Healthcare Information Systems. New York NY: Springer,2005, 30-55.

[51] G. K Esterberg. Qualitative methods in social research. United State: McGraw-Hill,2002, 154-161.

[52] S. B Merriam. Qualitative research in practice. Examples for discussion and analysis. New York: JosseyBass Inc Pub, 2002, 1-464.

[53] S. B Craig, C.E Hess, J.L McGinnis, et al. Leadership in University-Based Cooperative Research Centres. A Qualitative Investigation of Performance Dimensions. Industry and Higher Education, 2009, 23(5):367-77.

[54] H. Arksey, P.T Knight. Interviewing for social scientists. An introductory resource with examples. California US: SAGE Publications Ltd, 1999,1-224

[55] S. Kvale, S. Brinkmann. Interviews. Learning the craft of qualitative research. California, US: SAGE Publications Ltd. 2009, 43-230.

[56] D. J Cohen, B.F Crabtree. Evaluative criteria for qualitative research in health care: controversies and recommendations. The Annals of Family Medicine, 2008, 6(4): 9-331.

[57] O.M Mugenda. Research methods: Quantitative and qualitative approaches. African Centre for Technology Studies. Nairobi: African Center for Technology Studies (ACTS) Press,1999,1-256.

[58] D. Kasomo. Analysis of Research Methodology for Human Sciences. International Journal of Psychology and Behavioral Sciences, 2006. 27(6):12-20.

[59] N. James, H Busher. Ethical Issues in Online Educational Research. Protecting Privacy, Establishing Authenticity in Email Interviewing. International Journal of Research \& Method in Education, 2007,30(1):13-101.

[60] D. J Flinders. In Search of Ethical Guidance: Constructing a Basis for Dialogue. Qualitative Studies in Education, 1992, 5(2):15-101.

[61] D. Hanauer, E Dibble, J Fortin, et al. Internet Use Among Community College Students: Implications in Designing Healthcare Interventions[J]. Journal of American College Health, 2004, 52(5):197-202.

[62] P. Newhouse. Literature review: The Impact of ICT on Learning and Teaching. Western Australian Department of Education, 2002, 32(3):16-22.

[63] A. Loveless. Literature Review in Creativity. New Technologies and Learning. Journal of Distance Education, 2009;4(24):45-011.

[64] S. Shahmir, F. Hamidi, Z Bagherzadeh. Role of ICT in the Curriculum Educational System. Procedia Computer Science, 2011,3(23):6-623.

[65] M. Karimy, M Hasani, R Khoram, et al. The Effect of Education, Based on Health Belief Model on Breast Self-Examination in Health Liaisons of Zarandieh City. Zahedan Journal of Research in Medical Sciences, 2008,10(4):9-19.

[66] S. Livingstone. Critical Reflections on the Benefits of ICT in Education. Oxford Review of Education, 2012, 38(1):9-24.

[67] K. Samuelowicz, J.D Bain. Revisiting Academics' Beliefs About Teaching and Learning. Higher Education, 2001, 41(3):299-325.

[68] S. Mumtaz. Factors Affecting Teachers' Use of Information and Communications Technology. A Review of the Literature. Journal of Information Technology for Teacher Education, 2000, 9(3):42-319.

[69] A. Mondal, J Mete. ICT in Higher Education. Opportunities and Challenges. Institutions, 2012, 21(60):4-9.

[70] A. Abioye. Enhancing Library and Information, Science Education Through Cross-Borderland Collaboration. LIS Education in Developing Countries. The Road Ahead, 2014, 27(1):115:165.

[71] M. Levinson. Common Schools and Multicultural Education. Journal of Philosophy of Education, 2007, 41(4):42-625.

[72] A. Chaudhry, L.M Glodé, M Gillman, et al. Trends in Twitter Use by Physicians at the American Society of Clinical Oncology Annual Meeting, 2010 and 2011. Journal of Oncology Practice, 2012, 8(3):173-175. 